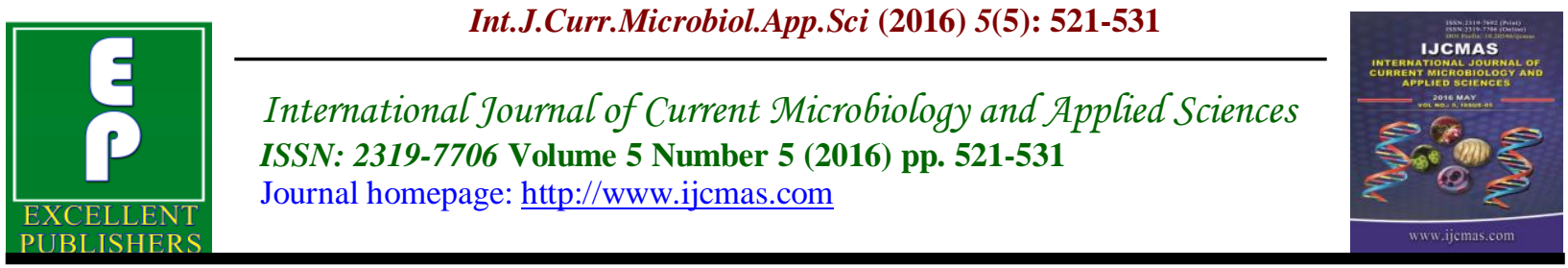

Original Research Article

http://dx.doi.org/10.20546/ijcmas.2016.505.054

\title{
Ultra Structural Changes in Rat Thyroid Gland Exposed to Fluoride
}

\author{
A. Shashi* and Parveen Kumar \\ Department of Zoology and Environmental Sciences, Punjabi University, \\ Patiala-147002, Punjab, India \\ *Corresponding author
}

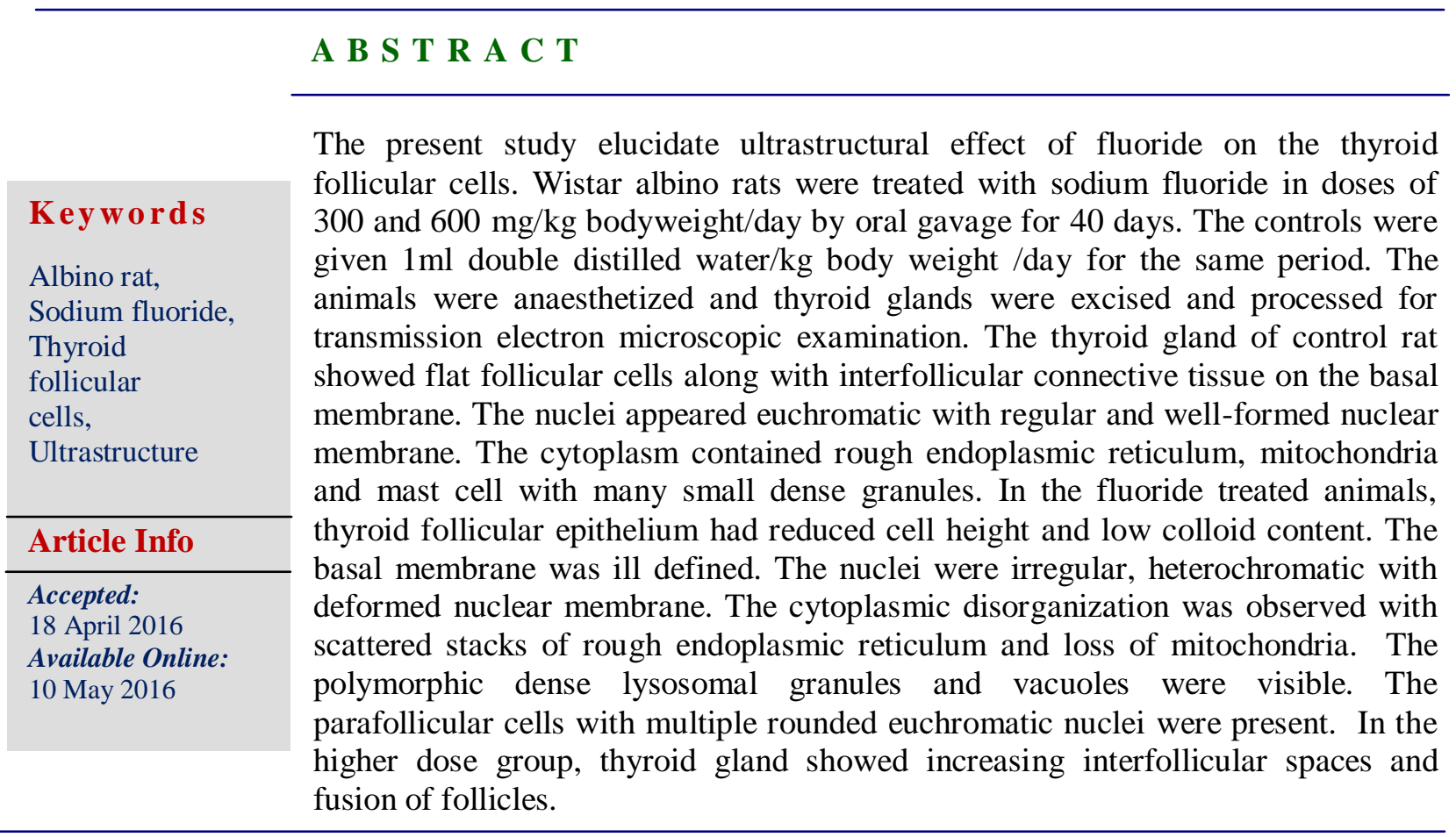

\section{Introduction}

Thyroid is the largest among vertebrate endocrine glands and is unique in that it stores secretory product (thyroid hormone) extracellularly. The thyroid follicle is the functional histological unit of thyroid gland. It is made up of three principal components; the lining follicular cells, the basal parafollicular cells and the luminal colloid. The follicular cells produce thyroid hormone (T3 and T4) which are essential for normal body metabolism, growth and development including reproduction, maturation and aging. The parafollicular cells produce mainly calcitonin that regulates calcium metabolism (Lu and Anderson, 1994; Shashi and Sharma, 2015).

The toxicity of long term fluoride exposure has been well documented in clinical studies (Shashi and Singla, 2013; Shashi et al., 2013). Though fluoride had strong effect on the function of thyroid hormone level (Jiang 
et al., 2011), the morphological examination of the thyroid gland can be more sensitive early indicator of thyroid gland activity. The main objective of this study is to provide information on the ultrastructural features of the thyroid gland in experimental fluorosis.

\section{Materials and Methods}

\section{Animals}

Young Wistar albino rats, weighing between $100-150 \mathrm{~g}$ were housed in polypropylene cages with stainless grill tops and fed with standard rat pellet diet (Hindustan lever limited, India) and water was given ad libitum. Animals were maintained at a constant room temperature of $20-22^{\circ} \mathrm{C}$ and $60 \%$ humidity.

The experiment were performed under the approval of the animal ethical committee of Punjabi university Patiala. (Animal maintenance and Registration No.107/99/CPCSEA/2014-37).

\section{Experimental Design}

Rats were allowed a 2- week acclimatization period and then they were divided randomly into three groups (6 rats each).

Group I This group served as a control and received $1 \mathrm{ml}$ double distilled water/kg bw/day orally daily by a gastric tube for 40 days.

Group II This group of rats received fluoride at a dose of $300 \mathrm{mg} / \mathrm{kg}$ bw/day for 40 days orally by gastric tube.

Group III This group received fluoride at a dose of $600 \mathrm{mg} / \mathrm{kg}$ bw/day for 40 days. The control and experimental animals were sacrificed under ether anaesthesia. The thyroid gland was dissected out, washed in normal saline and processed for ultrastructural examination.

\section{Electron Microscopy}

For transmission electron microscopic examination, fresh thyroid sample were fixed in $2.5 \%$ glutaraldehyde buffered with $0.1 \mathrm{M}$ phosphate buffer at $\mathrm{pH} 7.2$ for 2 hours at $4^{\circ} \mathrm{C}$ and then washed with the phosphate buffer, post fixed in $1 \%$ osmium tetraoxide in the same buffer for 1 hour at $4^{\circ} \mathrm{C}$. After washing in phosphate buffer specimens were dehydrated with ascending grades of ethanol and embedded in epoxy resin. Ultrathin sections of the thyroid were cut and double stained with uranyl acetate and lead citrate and examined using a Leo-435, VP, Japan electron microscope. All India Institute of medical Sciences (AIIMS), New Delhi.

\section{Results and Discussion}

In control rats (Group I) electron microscopy of thyroid gland showed the adjacent thyroid follicles filled with colloid (Fig 1). Follicular cell with rounded euchromatic nucleus with regular and well formed nuclear membrane and prominent nucleolus. Sub-epithelial basal membrane form the base of the cell. The cytoplasm has numerous paralleled cisternae of endoplasmic reticulum, dense polymorphic lysosomal granules, golgi bodies and mitochondria (Figs 2, 3). Ultrastructurally, the follicular cell showed the apical border with projecting microvilli towards the follicular lumen (Fig 4). Interfollicular connective tissue and mast cell with dense granules were observed (Fig 5).

In fluoride treated animals (Group II) by electron microscopy examination, the follicular cells of thyroid gland showing irregular nucleus with clumping of their peripheral heterochromatic chromatin. Numerous dilated irregular cisternae of endoplasmic reticulum (Figs 7,8). Many colloid droplets and vacuoles were observed (Fig 9). Some of these droplets were fused 
and formed large colloid masses (Fig 10). Parafollicular cell with multiple rounded euchromatic nucleus (Fig 11).

The fluoride treated animals (Group III) showed follicular cells with colloidal lumen and many colloid masses with vacuoles (Fig 12). Numerous vacuoles with many electron dense secretory granules (Fig 13) were seen.
Overall cytoplasm disorganization appeared with loss of mitochondria, endoplasmic reticulum and golgi bodies. Pyknosis of the heterochromatic nucleus and increase in interfollicular spaces. (Fig 14). Decrease in colloid content with increase in vacuolation detected in this group of fluoride treated rats.

Fig.1 An electron micrograph of ultrathin section of thyroid gland of control rat showing adjacent thyroid follicles filled with colloid (C). X 10000

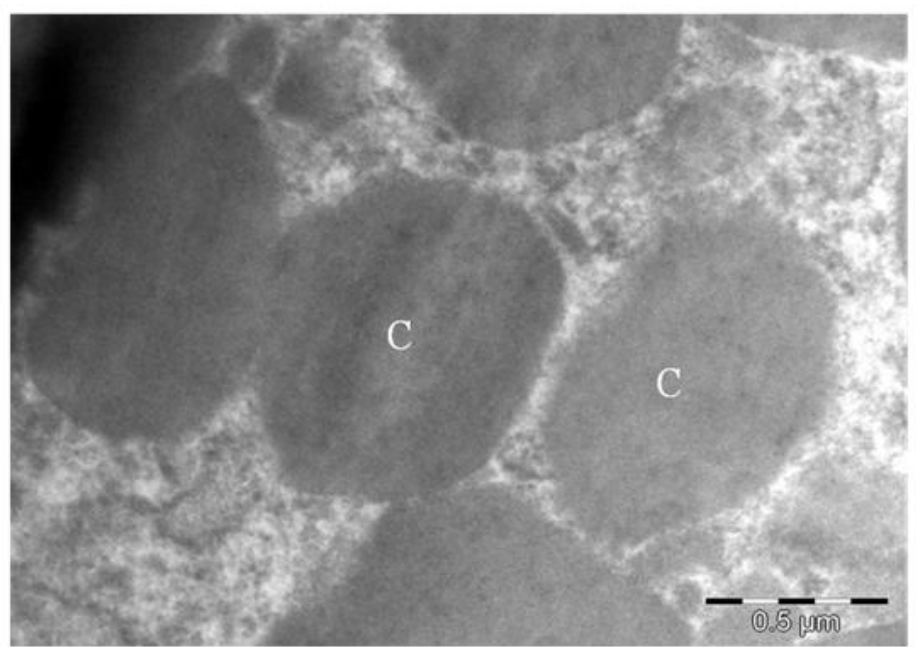

Fig.2 An electron micrograph of ultrathin section of thyroid gland of a control rat showing follicular cell with rounded euchromatic nucleus $(\mathrm{N})$ with regular and well formed nuclear membrane and prominent nucleolus. Sub-epithelial basal membrane (BM) forms the base of the cell. The cytoplasm has numerous paralleled cisternae of rough endoplasmic reticulum (ER), dense lysosomal granules (L) and mitochondria (M). X 4000

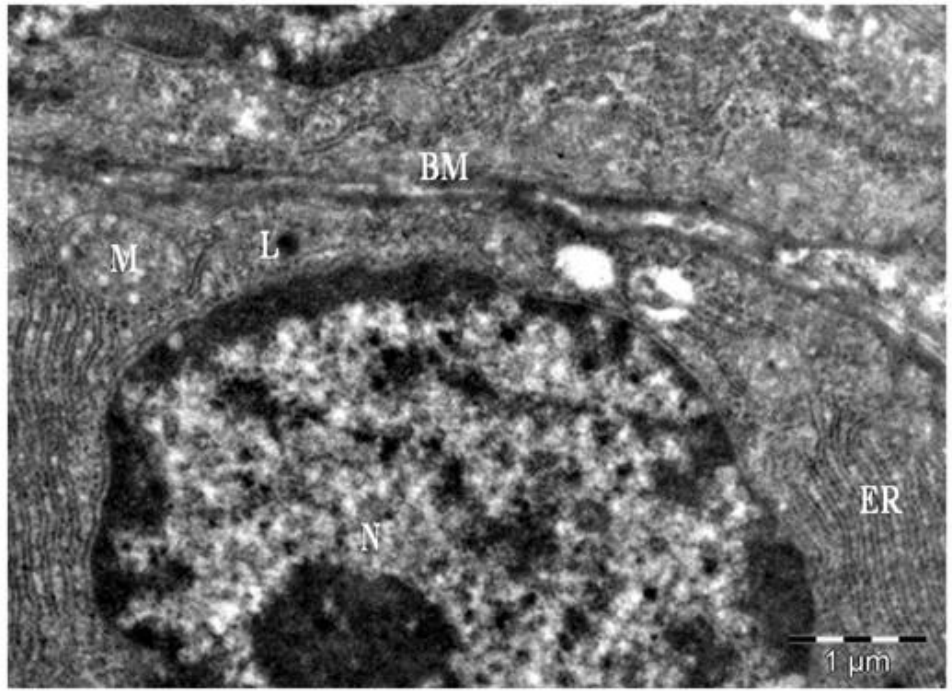


Fig.3 An electron micrograph of ultrathin-section of thyroid gland of control rat showing rounded euchromatic nucleus with well defined nuclear membrane in follicular cell. Their cytoplasm has numerous paralleled cisternae of endoplasmic reticulum (ER), mitochondria

(M) and golgi bodies (G). X 8000

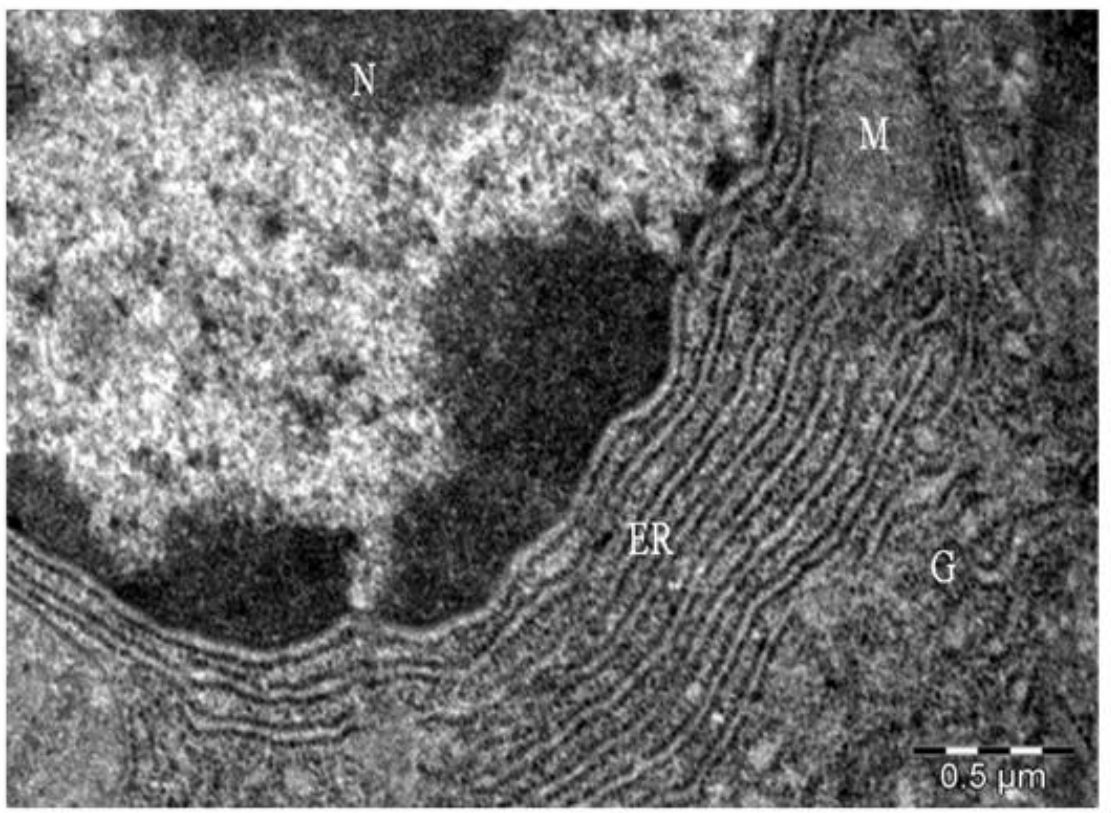

Fig.4 An electron micrograph of ultrathin section in the thyroid gland of control rat showing thyroid follicular cell. The cell showed the apical border with microvilli (MV) projecting to the colloidal lumen (CL), nucleus, endoplasmic reticulum (ER), and mitochondria (M). X

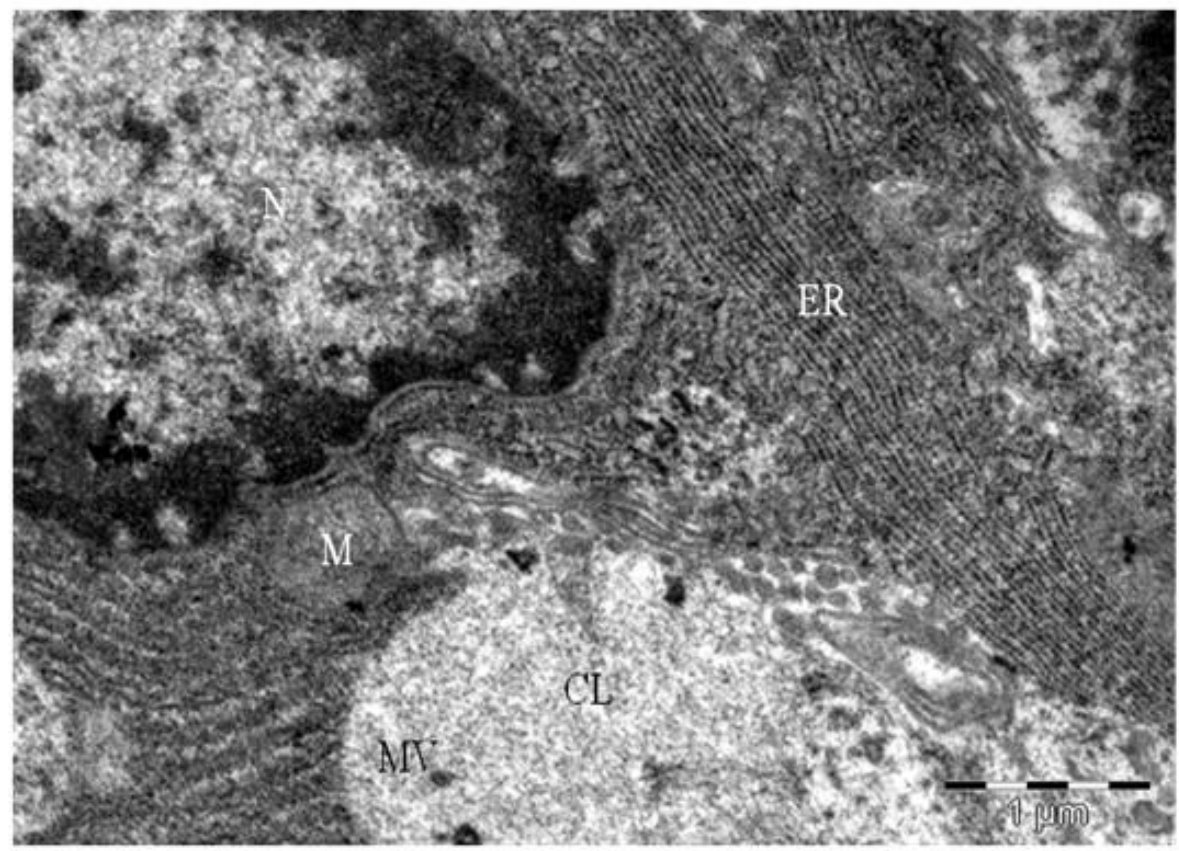


Fig.5 An electron micrograph of ultrathin section of thyroid gland of control rat showing the interfollicular connective tissue. Basal membrane (BM), the nucleus with regular and well formed nuclear membrane and prominent nucleolus $(\mathrm{N})$ is visible. Rough endoplasmic reticulum (RER) and mast cell (m) with dense granules are observed. X 3200

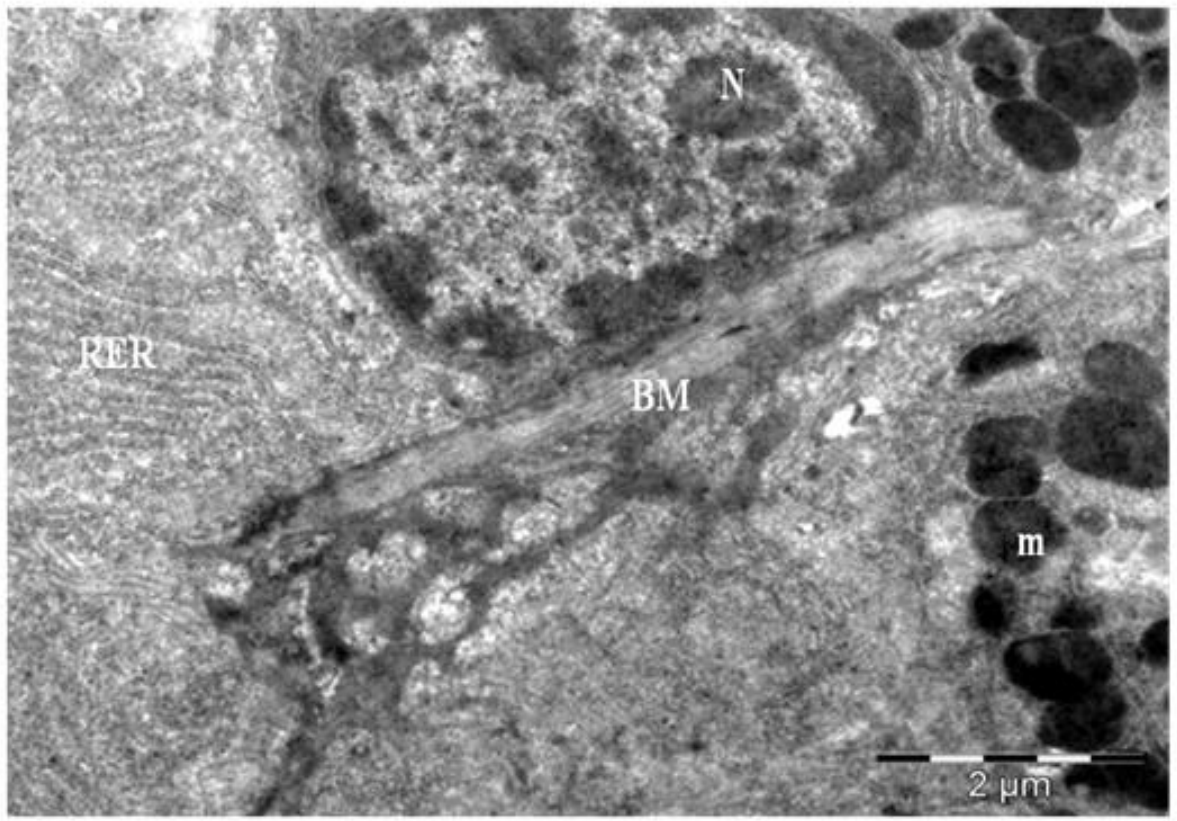

Fig.6 An electron micrograph of the thyroid gland of a control rat showing flat follicullar cells. The cytoplasm show cisternae of endoplasmic reticulum, few vacuoles and mitochondria (M). X 5000

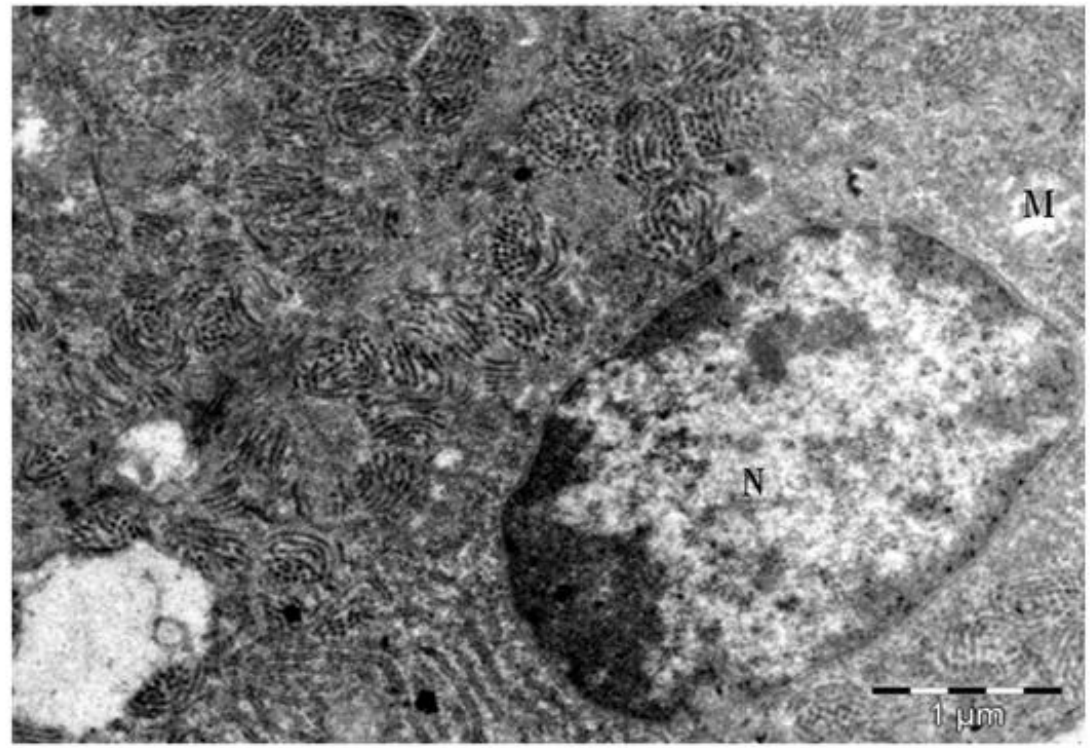


Fig.7 An electron micrograph of ultrathin section of thyroid gland of rat treated with $300 \mathrm{mg}$ $\mathrm{NaF}$ showing follicular cells with irregular nucleus $(\mathrm{N})$ alongwith clumping of their peripheral heterochromatin. Numerous dilated irregular cisternae of endoplasmic reticulum

(ER) are visible. X 4000

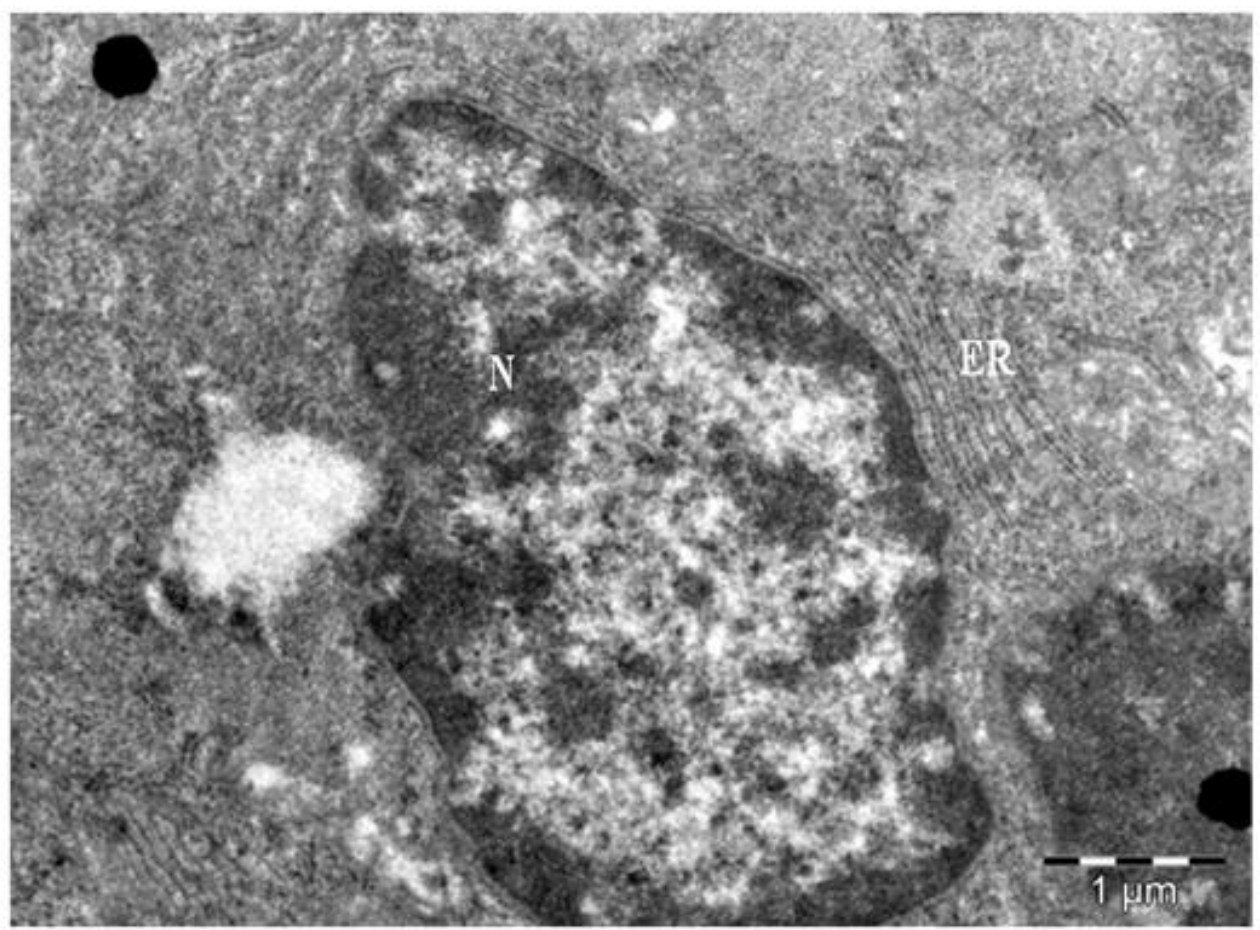

Fig.8 An electron micrograph of ultrathin section of thyroid gland of rat treated with $300 \mathrm{mg}$

$\mathrm{NaF}$ showing irregular nuclei $(\mathrm{N})$ with clumping of their peripheral heterochromatic chromatin. Numerous dilated irregular cisternae of endoplasmic reticulum (ER), colloid droplets and vacuoles (V) are visible. X 5000

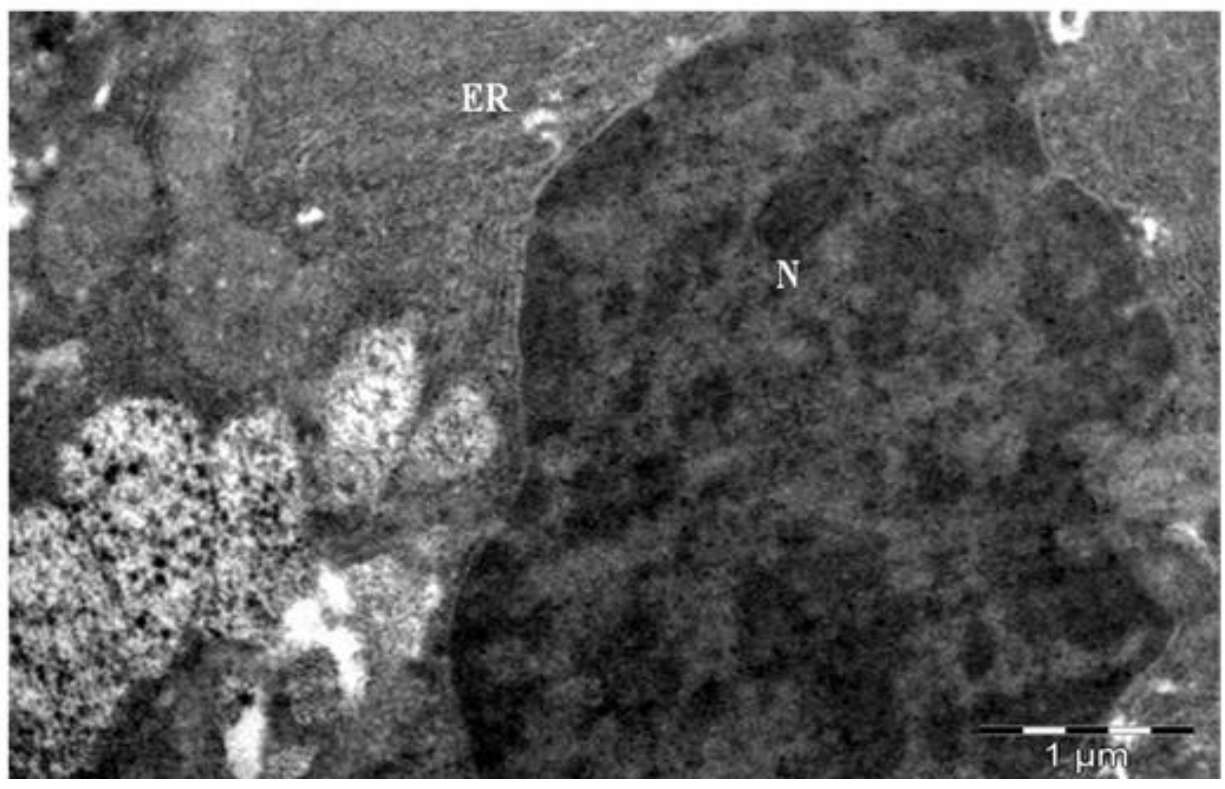


Fig.9 An electron micrograph of ultrathin section of thyroid gland of rat treated with $300 \mathrm{mg}$ $\mathrm{NaF}$ showing colloid droplets (C). X 5000

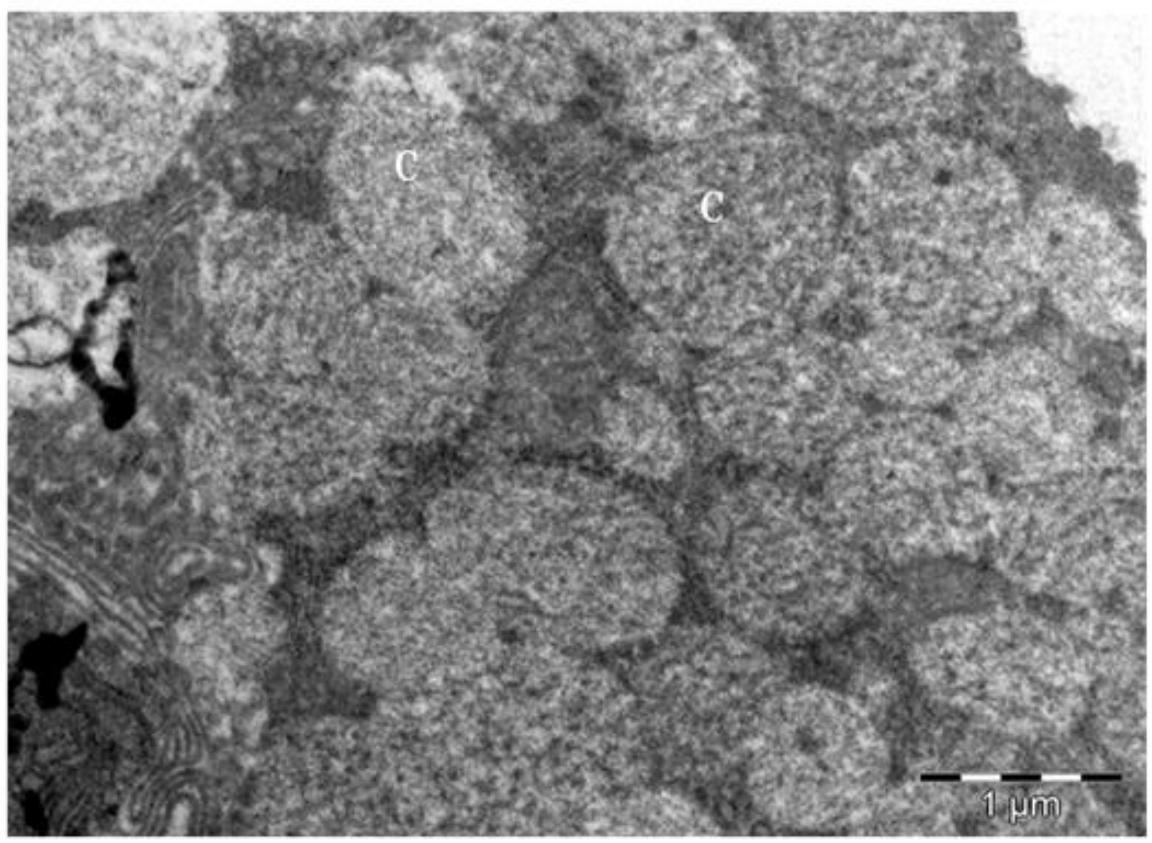

Fig.10 An electron micrograph of ultrathin section of thyroid gland of rat treated with 300 mg NaF showing endoplasmic reticulum (ER), mitochondria (M), small apical vesicles (V) and fusion of colloid droplets (C). X 5000

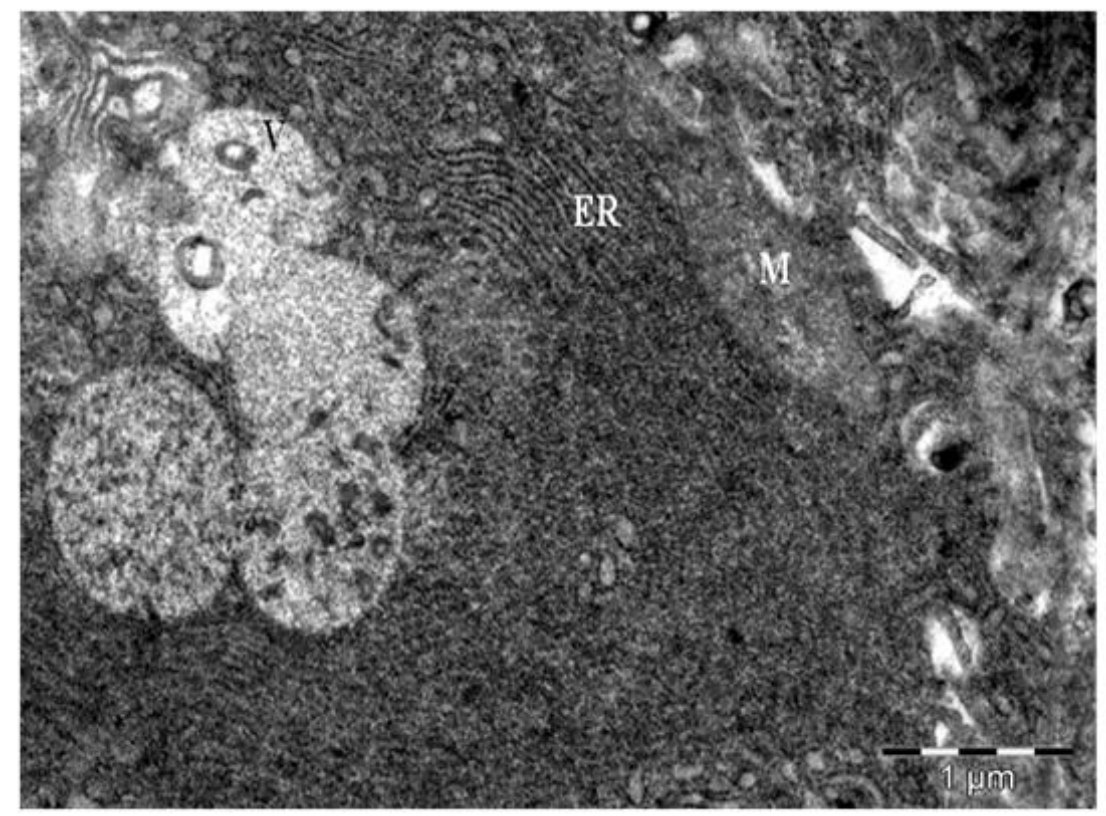


Fig.11 An electron micrograph of ultrathin section of thyroid gland of rat treated with 300 $\mathrm{mg} \mathrm{NaF}$ showing a parafollicular cell with multiple rounded euchromatic nuclei. X 2000

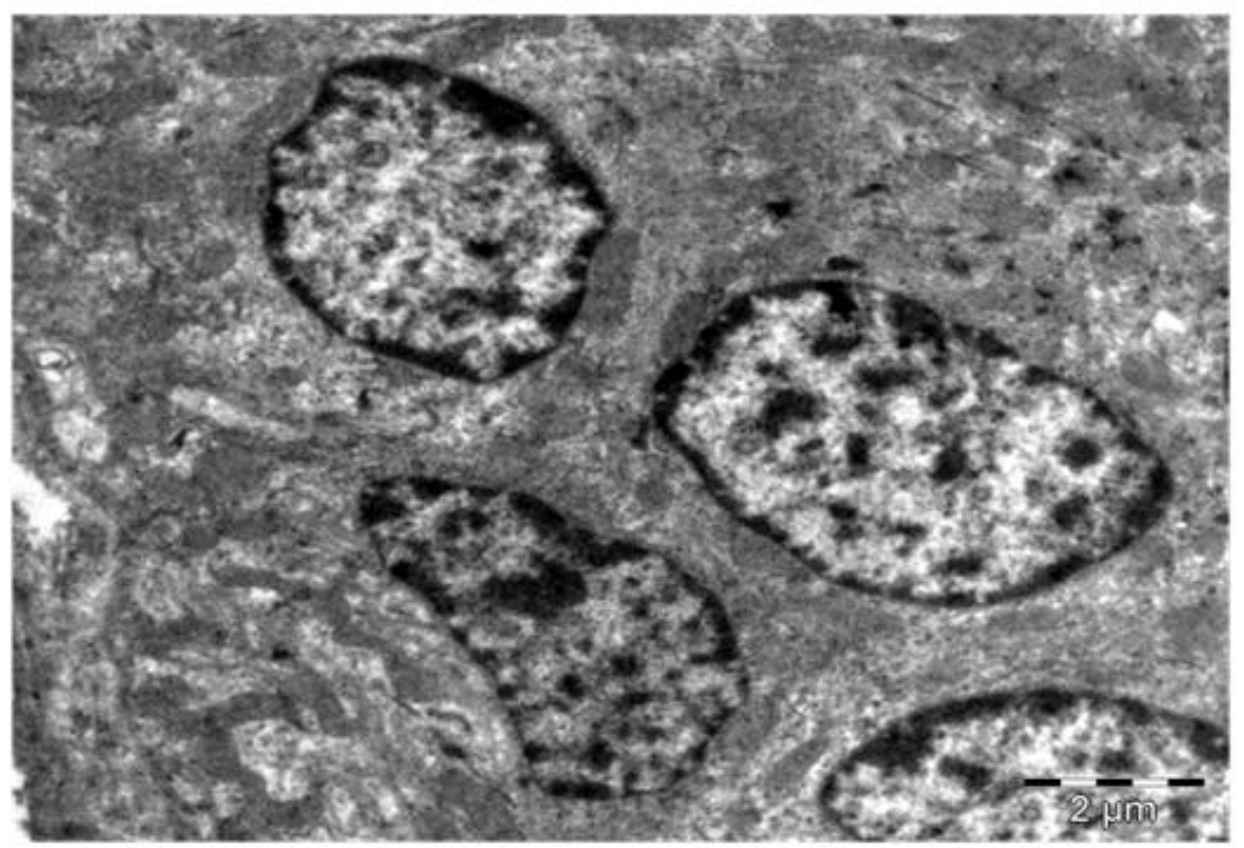

Fig.12 An electron micrograph of ultrathin section of thyroid gland of rat treated with 600 $\mathrm{mg} \mathrm{NaF}$ showing follicular cell with colloidal lumen and many colloid masses with vacuoles. Basement membrane (BM) is also visible. X 2000

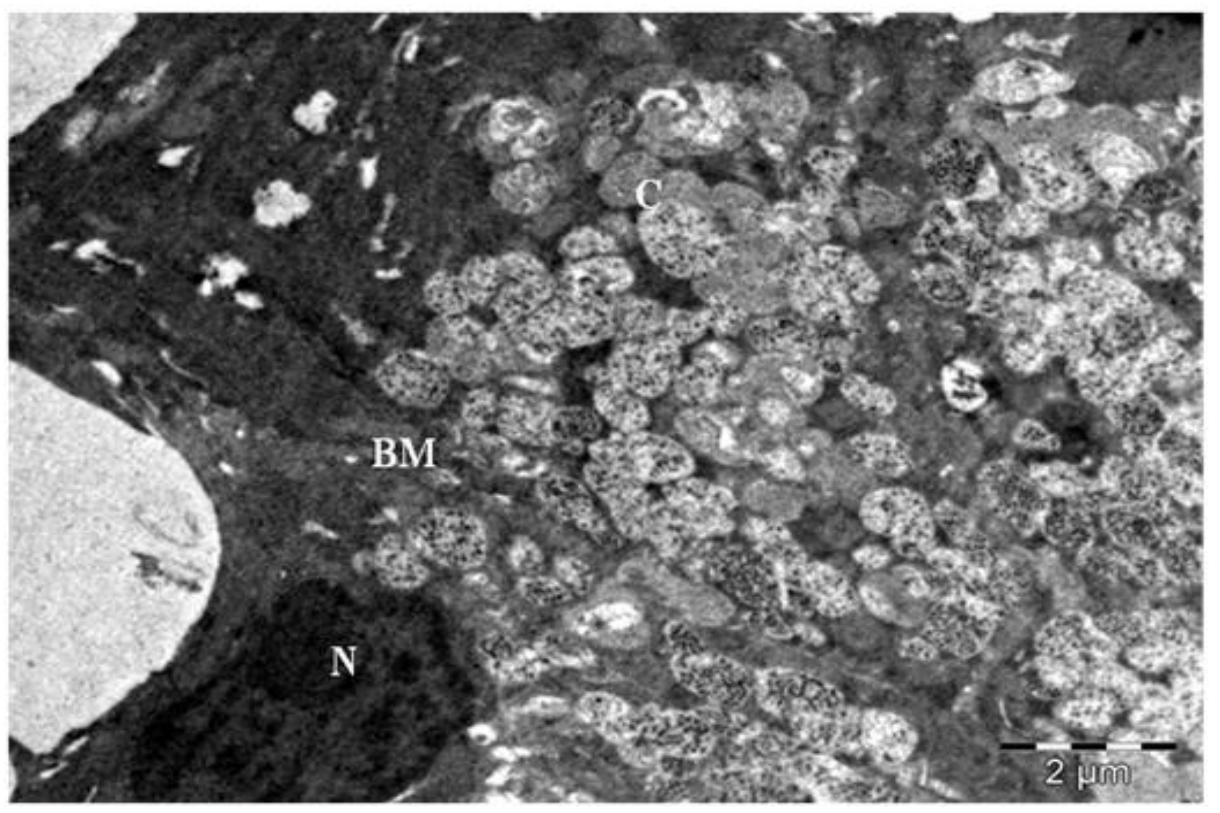


Fig.13 An electron micrograph of ultrathin section of thyroid gland of rat treated with 600 $\mathrm{mg} \mathrm{NaF}$ showing electron dense secretory granules and numerous vacuoles. X 3200

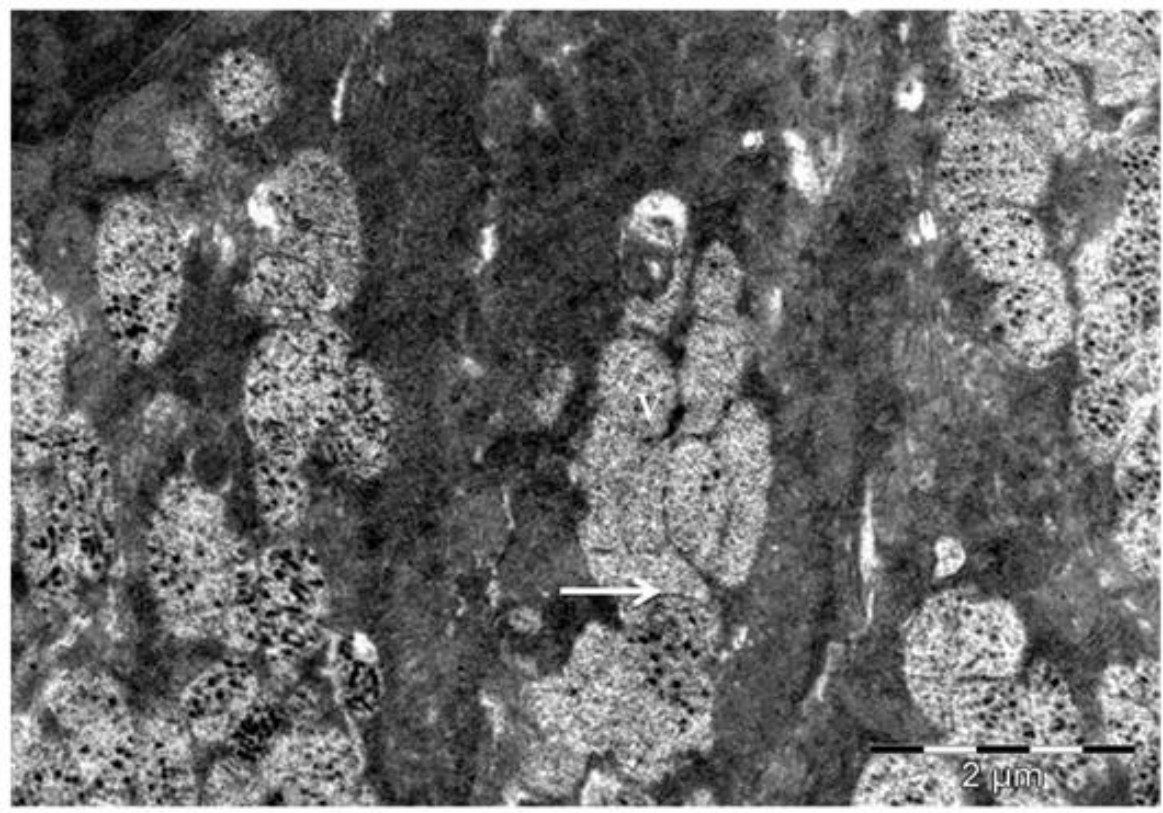

Fig.14 An electron micrograph of ultrathin section of thyroid gland of rat treated with 600 $\mathrm{mg} \mathrm{NaF}$ showing pyknosis of nucleus (arrow) and increase in interfoillicular spaces. X 2000

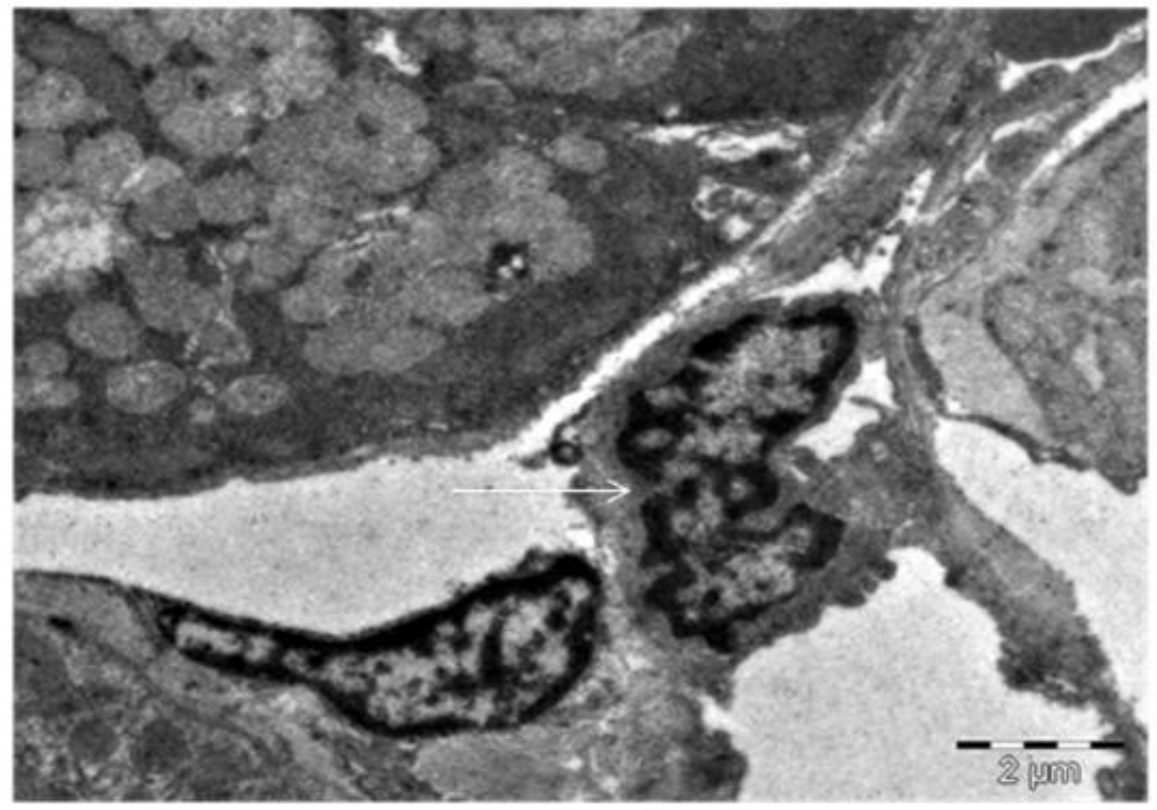

The cytoplasm of the follicular cells in the present study showed overall disorganization, the mitochondria were lost with scattered stacks of rough endoplasmic reticulum. This is in agreement with Zhan et al. (2006) who mentioned that excessive 
fluorine injured structure of thyroid gland including mitochondria and endoplasmic reticulum. Also, Zhan et al. (2005) investigated the effects of fluoride on the pancreatic acinar cells and found marked swollen mitochondria with loss of the cristae and the endoplasmic reticulum was markedly dilated. The loss of mitochondria in the present study could be explained by Shivarjashankara et al. (2001) who found that, lipid peroxidation induced by $\mathrm{NaF}$ impairs a variety of intra and extramitochondrial membrane system that may contribute to apoptosis.

The nucleus of the follicular cell in the present study appeared irregular in shape and heterochromatic with deformed nuclear membrane. This is in accordance with Agha et al. (2012) who found that, irregular shaped and heterochromatic nuclei are seen in the pancreatic cells of $\mathrm{NaF}$ administered group and this confirmed the induction of apoptosis. Also, Yu (2000) investigated the effects of fluoride on the ultrastructure in the tissue of liver, adrenal glands and thyroid glands of fetuses and found that the major pathological changes of nuclei were damaged and dilated vesicular dual layer structure of nuclear membrane. The study of Rehman and Fetouh (2013) reported that $\mathrm{NaF}$ had adverse effects on the follicular cells of the thyroid gland. NaF treated group showed the basal membrane was ill defined, colloid droplets appeared in the apical and basal part of the cytoplasm. Overall cytoplasmic disorganization was observed with scattered stacks of rough endoplasmic reticulum and loss of mitochondria and nucleus appeared irregular, heterochromatic with deformed nuclear membrane.

In the current work, alteration in the nuclear pattern and degenerative changes such as fusion of follicles and also expansion or dilatation of endoplasmic reticulum with loss of their lamellar arrangement. The nuclear changes and pyknosis were a result of glandular over stimulation. Nuclear changes were assumed to be one of these three patterns, all because of the breakdown of DNA and chromatins (Kumar et al. 2010).

Ultrastructurally, the gland of exposed rats showed that some follicles were lined by high cuboidal cells with clumping of peripheral hetrochromatin. Their cytoplasm contained several vacuoles and dense lysosomes. Dilated cisternae of rough endoplasmic reticulum contained amorphous electron-lucent content and lost their lamellar arrangement were also observed. Their apical borders showed a huge number of aggregated microvilli. In some cells, nuclei appeared often irregular in shape, shrunken with condensed heterochromatin.

Parafollicular cells had abnormal mitochondria with ruptured cristae and few granules. These results accepted and explained by Somozy (2000). It was reported that the cellular response to electromagnetic field is manifested as irreversible and reversible structure and functional changes to cells and their organelles.

Congestion observed in the vasculature of the thyroid gland was in agreement with Jubb et al. (1985) who attributed it to the excess demand for blood to nourish the follicular cells. Moreover, (Burton and Foster, 1995) explained these vascular changes by the effect of free radicals production and lipid peroxidation induced by radiation. It could be concluded that, fluoride induced proliferative changes in both follicular and $\mathrm{C}$ cells. Also, it induced degenerative changes in follicular cells with decreased colloid production. 


\section{Acknowledgment}

TEM studies were carried out at the Sophisticated Instruments Facility for EM at the All India Institute of Medical Sciences, New Delhi, India.

\section{References}

Agha, F.E., E.I-Badry, M.O., Hassan, D.A.A. and Abdelraouf, A.A. 2012. Role of vitamin $\mathrm{E}$ in combination with methionine and 1-carnosine against sodium fluoride-induced haematological, biochemical, DNA damage, histogical and immunohisto-chemical changes in pancreas of albino rats. Life Sci. J., 9(2): 1260-1275.

Burton, G., Foster, D.O. 1995. Biological antioxidant. Phiolos. Trans. Soc. Lend. Brol. Sci., 331: 565-578.

Jubb, K.V., Kennedy, P.O., Palmer, N. 1985. Pathology of domestic animals. Academic press, San Diego. 266-280.

Kumar, V., Abbas, A.K., Fausto, N. and Aster, J.C. 2010. Endocrine system in Robbins and Cortan pathologic basis of disease. 8th ed. Saunders, Elsevier Inc. 10961164.

Lu, M.H., Anderson, R.R. 1994. Thyroxine secretion rats during pregnancy in the rat. Endocrine Res., 20: 343-364.

Rehman, M.M.A., Fetouh, F.A. 2013. Effect of sodium fluoride on the thyroid follicular cells and the amelioration by calcium supplementation in albino rats : A light and electron microscopy study. $J$. American Sci., 9(10): 107-114.
Shashi, A., Sharma, N. 2015. Alterations in lipid metabolism in patients of thyroid hyperfunction. Int. J. Basic App. Med. Sci., 5(1): 75-85.

Shashi, A., Sharma, N. 2015. Goitrous thyroiditis: clinical and pathological implications. Int. J. Basic App. Med. Sci., 5(1): 152-157.

Shashi, A., Singla, S. 2013. Syndrome of low triiodothyronine in chronic fluorosis. Int. J. Basic App. Med. Sci., 3(1): 152-160.

Shashi, A., Upasana Devi, Singla, S. 2013. Clinical study of insulin resistance in diabetic patients with subclinical and clinical hypothyroidism. Int. J. Basic App. Med. Sci., 3(2): 400-412.

Shivarajashankara, Y.M., Shivashankara, A.R., Hanumanth, R.S., Gopalkrishan, P.B. 2001. Oxidative stress in children with endemic skeletal fluorosis. Fluoride, 34: 103-107.

Singla, S., Shashi, A. 2015. Thyroid peroxidase activity as toxicity target for fluoride in patients with thyroid dysfunction. Curr. Res. Microbio. Biotech., 1(2): 53-57.

Smozy, Z. 2000. Radiation response of cell organelles. Micron, 31:165-181.

Yu, Y.N. 1985. Effects of chronic fluorosis in the thyroid gland. Chinese Med. J., 65: 747-749.

Zhan, X.A., L.I. JX., Xu, Z.R., Wang. 2005. Effects of fluoride on pancreatic digestive enzyme activities and ultrastructure in young pigs. Fluoride, 38(3): 215-219.

Zhan, XA., L.I. JX., Xu, Z.R., Wang. 2006. Effects of excessive feed fluorine on structure and function of thyroid gland in piglets. J. Chinese Cereals and Oils Assoc., 01.

\section{How to cite this article:}

Shashi, A., and Parveen Kumar. 2016. Ultra Structural Changes in Rat Thyroid Gland Exposed to Fluoride. Int.J.Curr.Microbiol.App.Sci. 5(5): 521-531. doi: http://dx.doi.org/10.20546/ijcmas.2016.505.054 